\title{
Triple Headed Patriarchal Hydra: Masculinities and Violence against Women in Nepal ${ }^{\mathrm{i}}$
}

\author{
Sanjeev Uprety \\ Mphil Program in English, Tribhuvan University, Nepal
}

Copyright $\mathrm{C} 2016$ by authors, all rights reserved. Authors agree that this article remains permanently open access under the terms of the Creative Commons Attribution License 4.0 International License

\begin{abstract}
This study has made an attempt to study the nexus between patriarchy and violence against women by discussing three interrelated aspects of patriarchy in Nepal: social norms, social structure and law. Research findings show how these three aspects - or the three heads of the hydra, to put it metaphorically--shape and reinforce each other rather than functioning as separate domains. In other words, social norms concerning what it means to be a man or woman not only reinforce greater presence of men in leadership positions in various public institutions - including police, courts and media that are deeply involved in the law and justice mechanism concerning violence against women--but also impact the implementation of law while it comes to cases of VAW. In the same way, current law implementing mechanisms in Nepal reinforce older social norms concerning masculinities and femininities. Due to such an interconnectedness of these three domains - norms, structure and law, it is necessary to deal with them together in order to fight against VAW. This is to say that the three headed hydra of patriarchy can be defeated only if efforts are made to cut all three of its heads simultaneously.
\end{abstract}

Keywords Maculinities, VAW, Nepal, Law, Social Norms, Social Structure, Patriarchy

\section{Introduction}

Current research shows that masculinity (like femininity) is not singular but plural. A number of masculinities studies scholars such as Michael Kimmel (2008), R.W Connell (1995), Shareen Benjamin (2001) and Alex Broom (2004) have argued that there is no universal model of masculinity; rather, there are multiple masculinities shaped by a variety of factors including class, ethnicity, institutional and political location, as well as patterns of consumption. However, the dominant forms of masculinities that circulate within the social fabric repress these plural masculinities and promote only the version that is associated with domination, aggression and violence. Since many men internalize such traditional forms of masculinity while growing up, they often display dominance and aggression during their interactions with women. Many men also feel a sense of psychological lack because they are unable to approximate the model of ideal masculinity traditionally associated with physical strength, economic power, emotional control and sexual capacity. They try to deal with such a sense of lack by displaying violent behavior-physical or mental-- towards women, children, transgender subjects and other men who are in lower social and economic positions. At the same time, violent behavior of men - either physical or psychological and emotional-cannot be reduced to the issue of psychological lack. Such violence is often condoned and legitimized by perpetual circulation of prevailing social norms but also by exiting social structure within which most men enjoy more privilege and power than most women and transgender subjects. Such a nexus of social structure and social norms, in turn, shapes both the making and the practice of law.

Since masculinities studies is a new area in Nepal, a lot needs to be done in order to understand various aspects of Nepali masculinities, including their relation to caste and class, as well as their multiple historical and political manifestations. However, studies done by scholars like Pratyoush Onta, Jeevan R. Sharma and Matt Maycock have prepared the base for further research concerning Nepali masculinities. Pratyoush Onta's work concerning the construction of Bir (brave) Nepali history, though it does not directly deal with the issues concerning masculinities, points to historical imperatives that might have shaped the construction of Nepali masculinities (1996). Sanjeev Uprety's study titled "Masculinity and Mimicry: Ranas and Gurkhas" is another example of a study that analysis Nepali masculinities from a historical perspective (2011). Also important is the work done by Matt Maycock regarding the masculinities of kamaiyas (bonded laborers) living in Kailali district of far-west Nepal (2012) and so too is the work done by Jeevan R. Sharma concerning Maoist masculinities.

Nepal has been represented in various historical and literary texts as a "brave masculine nation," especially due to the legacy of the Gorkha soldiers who fought in various 
battlefields around the world. Pratyoush Onta's work concerning the construction of Bir (brave) Nepali history, though not directly dealing with the issues concerning masculinities, points to historical imperatives that might have shaped the construction of Nepali masculinities (1996). Onta's central argument is that historical and literary figures like Bhanu Bhakta Acharya and Bal Krishna Sama were projected as carrying on the tradition of other bir (brave) heroes of the nation such as Prithivi Narayan Shah and Bal Bhadra Kunwar. Sanjeev Uprety's study titled "Masculinity and Mimicry: Ranas and Gurkhas" is another example of a study that analysis Nepali masculinities from a historical perspective (2011). These studies show that masculinities function at the heart of Nepali nationalism, with dire consequences for woman and other genders. Since masculinities are tied, within the frame of such "nationalistic imagination," with attributes of aggression, violence and domination, women and other genders sometimes become the recipients of same aggression at the domestic, household and community level. Just as male Gorkhali soldiers "proved" their masculinity by displaying aggression and violence in the battlefield, many Nepali men display similar violence in the domestic sphere to be seen as "real men." Uprety's research has also shown that there is indeed a linkage between military violence and domestic violence, with many respondents in Kathmandu saying that a civilian man who carries arms and knows how to use them is more masculine than the one who neither possesses nor knows how to use the weapons (2014). This is part of the patriarchal world view that associates masculinities with violence and aggression. For this reason, it is crucial to unpack the association between masculinities and violence, including violence against women.

The studies discussed above illuminate some important aspects concerning Nepali masculinities. They show how masculinity underlies institutional (political parties) and public spaces (public transport), how caste and sexuality shape people's perceptions concerning masculinity, and how social stigmas are generated via those perceptions. Since masculinities are plural, fluid and take multiple forms depending on social, political and economic contexts, a lot more needs to be done in order to understand various trajectories of Nepali masculinities, including the relationship between masculinity and gender based violence. It is hoped that the current research will contribute in this area while simultaneously exploring the nexus between Nepali masculinities and violence against woman. It is also hoped that the research will able to shed light on the interrelationship between law, social structure and social structure besides discussing how such a linkage supports both traditional notions concerning masculinities, as well as patriarchal value systems promoting violence.

\section{Materials and Method}

\subsection{Methodologies and Locations}

This research has used both the quantitative (administering questionnaire) as well as qualitative (life history) methodologies. The questionnaire was administered in a sample size of 70, including men, women and trans-gender people from Kathmandu valley, developed for this study. The sample included people from various wakes of life including those working in NGOs and in legal profession, in addition to drivers and their helpers in public vehicles, plus two and graduate students, college level teachers, people from transgender community, known perpetrators of sexual and gender based violence, men in police custody and people doing manual work in marketplace.

These locations were chosen with the aim of representing people who either perpetrate violence against women (known perpetrators, men in custody), who witness such violence (marketplace, public vehicles, educational institutions), who fight against it (as NGO workers involved in Occupy Baluatar Movement), ${ }^{1}$ or who deal with such violence as part of their professional life (paralegal and NGO professionals). In addition to the surveys, ten audio interviews were conducted. Of these, there were six in depth life history interviews seeking to understand the behavior of men in various wakes of life. Apart from these, four more interviews were conducted to illicit the responses of people who have to deal with the issues of gender violence on a daily basis in their capacities as lawyers, policemen or LGBTI activists.

For the purpose of maintaining the privacy of the respondents, the names, surnames and places of those participating in the life history have been altered. The names of the two lawyers Meera Dhungana and Sashi Acharya who were also interviewed, however, has been retained following the permission of the interviewees. The quantitative and qualitative methods used in the research supplement each other with the questionnaire eliciting information concerning what respondents think are the essential attributes of masculinities, and life history interviews showing how they interpret and "perform" the same deeply held beliefs in their everyday lives.

\subsection{Limitations}

The current research might be shaped by the urban context in which it was conducted. The urban context of the study might have shaped some of the liberal responses encountered during the research. Further research in the rural areas of Nepal outside the valley might revise some of the findings and conclusions of the present study.

Similarly, since the focus was on masculinities in relation

1 Occupy Baluatar was a peaceful protest movement calling on the Nepali state to better address the widespread problem of impunity and gender-based violence, where protesters organized to sit in front of the Nepalease Prime

Ministers' Residence for more than hundred days 
to gender-based violence more men $(71.42 \%)$ than women $(14.28 \%)$ or trans gender people $(14.28 \%)$ were included in the study. The main focus was on how men experience their masculinities and how certain internalized norms concerning what it means to be a man lead them towards violence. For this reason, more men were included in the sampling process. At the same time, women and trans genders, too, were included in the sampling process with the aim of understanding alternative understandings of masculinities. While the latter aim was not the main goal of the research, it was felt that such a counter perspective was necessary to shed light into the overall social processes involving the production and circulation of masculinities. A wider sampling involving more women and trans gender subjects might help to understand the perspectives of women and transgender people from a broader perspective.

The study was done around certain specific institutional or public locations where gender based violence is witnessed, perpetrated or dealt with, including NGOs, police stations, educational institutions, legal profession, public vehicles and marketplace. Samplings done in other locations, such as factory outlets, restaurants, agricultural work space and so on might yield not only a different representation in terms of class, education, age, caste and gender, but also slightly different perspectives concerning masculinities in relation to gender based violence. Also, a broader sample size might have revealed additional knowledge concerning the relationship between masculinities and violence against women in Nepal.

\section{Discussion}

\subsection{Social Norms: Persistence of Old Stereotypes}

While the post 2009 politico-social scenario of Nepal shows some liberal attitudes regarding gender this does not mean, however, that older stereotypes regarding masculinities and femininities have ceased to function. Traditionally masculinities are associated with physical attributes such as height, physical strength, muscular body and fertility. Such an association was reproduced in the survey as high percent of the respondents, when given an option of selecting among the listed attributes, chose height and physical strength (45.71\%), muscular body $(34.28 \%)$ and fertility or ability to impregnate a woman $(32.85 \%)$ as major attributes of masculinities. Similarly, regarding the non-physical attributes of masculinities, majority of the participants chose rationality/ intellectuality $(62.85 \%)$, bread winning ability $(45.71 \%)$, forming family through marriage (40.00), political affiliation (34.28\%), and having more than one girlfriend (11.42\%). Such associations that link masculinities with physical or non-physical attributes such as physical strength, rationality, intellectuality and bread winning ability merely reproduce the traditional ideology where men are seen not only physically stronger in comparison to women, but also as more rational, more intelligent, and with greater capacity of making money for the family than women.

In addition, the survey shows that most respondents still associate masculinities with aggression. Thus $41.42 \%$ of all participants completely agree with the statement that men are naturally aggressive while $34.28 \%$ show partial agreement. By contrast, only $15.71 \%$ completely disagree with the idea that there is a natural connection between masculinities and aggression while $8.57 \%$ show partial disagreement. The idea that aggression is primarily the domain of men was reconfirmed when the respondents were confronted with another statement: if a girl beats up the man or humiliates him publicly, its takes away from his manhood. Out of the 70 respondents in the Kathmandu valley 36 (51.42\%) completely agreed with this statement and 9 (12.85\%) partially agreed to it while only $19(27.14 \%)$ recorded complete disagreement and 6 people $(8.57 \%)$ said they partially disagreed. This only shows that most men feel that they must put up a show "masculine aggression" which comes to them naturally, and that their masculinity will be undermined if they become victim of aggression themselves, especially if such aggression comes from women.

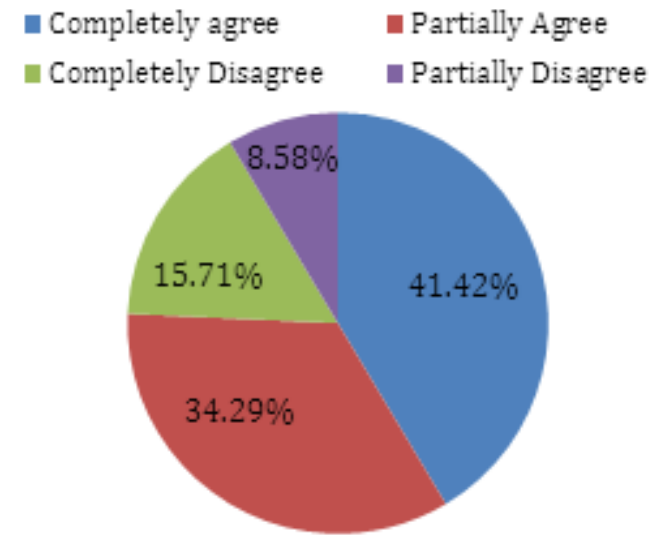

Men are by birth violent/dominant/aggressive

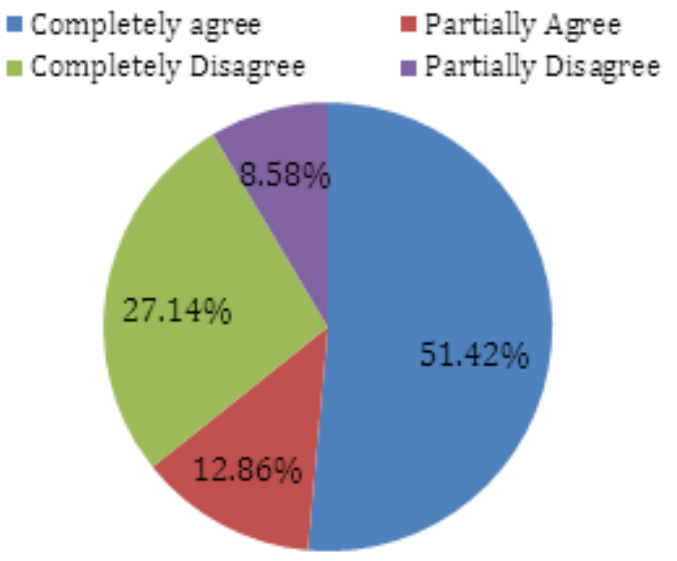

If a girl beats up the man or humiliates him publicly, its takes away from his manhood

\subsection{Internalization of Patriarchal Social Norms: Women and TG Subjects}


The research showed that just like men, women and transgendered subjects, too, tend to internalize traditional concepts concerning masculinities. Thus, while $48 \%$ men in the Kathmandu valley said that height and physical strength are the major physical characteristic of masculinities, $30 \%$ women respondents echoed the same views. Similarly, while $64 \%$ men chose rationality/ intellectuality and $48 \%$ chose bread-winning ability as the crucial markers of masculinities, $50 \%$ women echoed the same views regarding rationality/ intellectuality and $30 \%$ in relation to breadwinning ability. This shows that ideology is not limited to a particular gender, and that similar ideological beliefs can shape the subjectivities of both men and women.

This connection between social norms and gendered subjectivity was even more pronounced in the case of transgender subjects. A number of gender theorists, including Judith Butler have maintained that transgender performances disrupt normative ideas concerning masculinities and femininities (1993). While this might be true, the research showed that a number of transgender subjects might perpetrate the same old ideas concerning masculinities and femininities rather than disrupting those ideas in their everyday lives. Thus $50 \%$ of the third gender respondents in the valley said that height and strength are the major physical characteristics of masculinities, while $70 \%$ chose rationality/ intellectuality and $60 \%$ selected breadwinning ability as the major non-physical attributes of the same. What is interesting is that the percentage of $\mathrm{TG}$ subjects who chose these attributes was higher than that of male respondents who had selected the same. Thus although only $48 \%$ men in the Valley had said height and strength were the major markers of masculinities, $50 \%$ of TG people said that same thing; similarly, while only $64 \%$ of men had selected rationality/ intellectuality as the major non-physical attribute of masculinities $70 \%$ of TG subjects echoed the same views. The same pattern was repeated in the case of other non-physical attribute (breadwinning ability) that was rated highly by all respondents: compared to only $48 \%$ men, $60 \%$ TG subjects said that this was a crucial characteristic of masculinities.

Examination of the responses to the statement "men are naturally aggressive" showed a similar pattern: while $74 \%$ men in the Valley completely $(42 \%)$ or partially $(32 \%)$ agreed with this statement, $60 \%$ women showed a similar agreement with $40 \%$ showing complete agreement and $20 \%$ recording partial agreement. This merely shows that while modern Nepali women, especially in the urban areas, are trying to break away from the traditional ideologies concerning gender, majority of them still hold onto the same social norms as their male counterparts. It is possible that such feminine internalizations concerning gender might be even more pronounced in the rural areas of Nepal.

A study of the responses of TG subjects concerning this statement merely reconfirmed that observation that was made earlier: while TG performances might disrupt the traditional notions concerning masculinities and femininities, many TG subjects continue to display the same old attitudes concerning what it means to be a man or a woman in their everyday lives. Thus $80 \%$ TG respondents in the Valley agreed with the statement "men are naturally aggressive" either completely $(40 \%)$ or partially $(40 \%)$; a percent that was higher than that of both men $(74 \%)$ and women $(60 \%)$ who had agreed with the same statement.
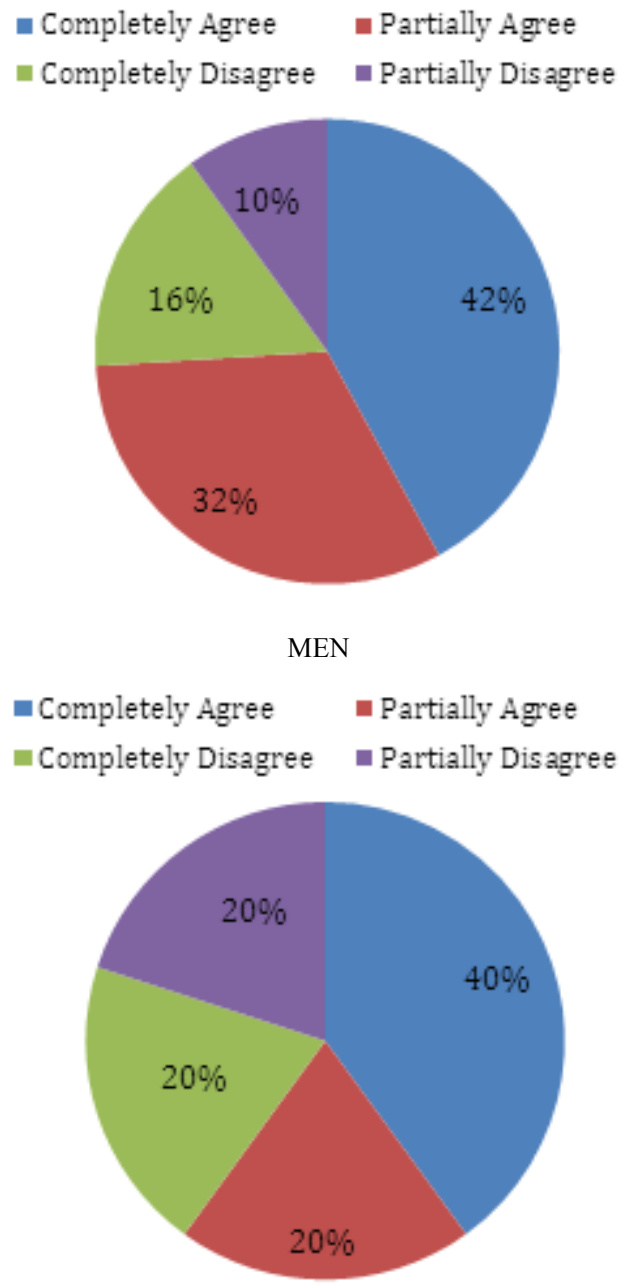

WOMEN

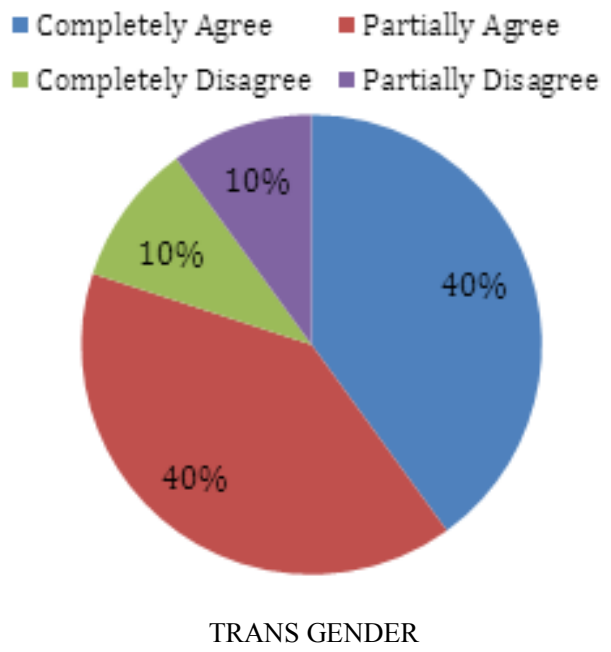

Men are naturally aggressive 


\subsection{Social Norms, Masculinities and Sexuality}

The study also showed the persistence of certain ideologies concerning masculinities in relation to sexuality. $78.56 \%$ of the respondents in the Valley, for example, agreed either completely $(45.71 \%)$ or partially $(32.85 \%)$ that men are by nature sexually polygamous and tend to have more than one sexual partner. In comparison only $21.42 \%$ of the respondents disagreed with such statement, with $17.14 \%$ disagreeing completely and $4.28 \%$ showing partial disagreement.

Similarly $60 \%$ respondents in the Valley either agreed completely $(40 \%)$ or partially $(20 \%)$ with the statement "a boy/man can have affair with several girls simultaneously as long as he can hide it from others." In contrast, only $39.99 \%$ disagreed with such perception, with $32.85 \%$ disagreeing completely and $7.14 \%$ disagreeing partially.

There were significant differences concerning men and women when it came to social expectations concerning sexual behavior. For example $65.71 \%$ respondents in the Valley agreed either completely (40\%) or partially (25.71) when asked if a man or a boy can pay for sex or go to a sex worker to gain the experience of making love. But a similar question concerning a girl or women yielded different results. Thus when confronted with the statement that a girl or a woman cannot pay for having sex with others $72.85 \%$ of the participants agreed either completely $(50 \%)$ or partially $(22.85 \%)$. In other words, while the majority of the participants $(65.71 \%)$ agreed that it was okay for the boys to pay for sex, the idea that girls or a women cannot pay for having sex was endorsed by an even greater majority $(72.85 \%)$, thus representing two totally opposite social expectations regarding men and women concerning sexual behavior

Similar social divide also manifested when it came to the question of pre-marital sex, with the majority of the participants in the Valley saying it was all right for a boy or a man to have sexual relations with girls before marriage while simultaneously rejecting similar freedom where women or girls were concerned. Thus $65.70 \%$ of the participants agreed either completely $(41.42 \%)$ or partially $(24.28 \%)$ that it was okay for boys or men to have sexual relationship with girls or women before marriage. In contrast, only $45.71 \%$ agreed either completely $(18.57 \%)$ or partially $(27.14 \%)$ with the statement that it is okay for a girl or a woman to have pre-martial sexual relationship. Also, while only $34.27 \%$ of the total participants disagreed either completely $(22.85 \%)$ or partially $(11.42 \%)$ with the statement that it is okay or boys or men to have pre-marital sex, the numbers went much higher when it came to rejecting pre-marital sex concerning women. Thus $54.28 \%$ said that they either completely $(47.14 \%)$ or partially $(7.14 \%)$ disagree with statement that it is all right for a girl or a woman to have sex before marriage.
In other words, the findings reveal that there are different social expectations concerning men and women when it comes to sexual behavior. Since most people consider men naturally polygamous, there is a greater acceptance when men or boys go to sex workers, or when they engage in pre-marital or extra-marital sexual activities. This not only makes them more susceptible to sexually transmitted diseases, which they can pass onto their partners thus affecting the reproductive health of the family, but also makes them more susceptible to the temptations of adultery. This in turn can lead to mental suffering on the part of their wives/ partners who are expected to either accept or to forgive the deviations of their husbands because of the social perceptions that men are naturally polygamous just as women are tolerant and forgiving by nature.

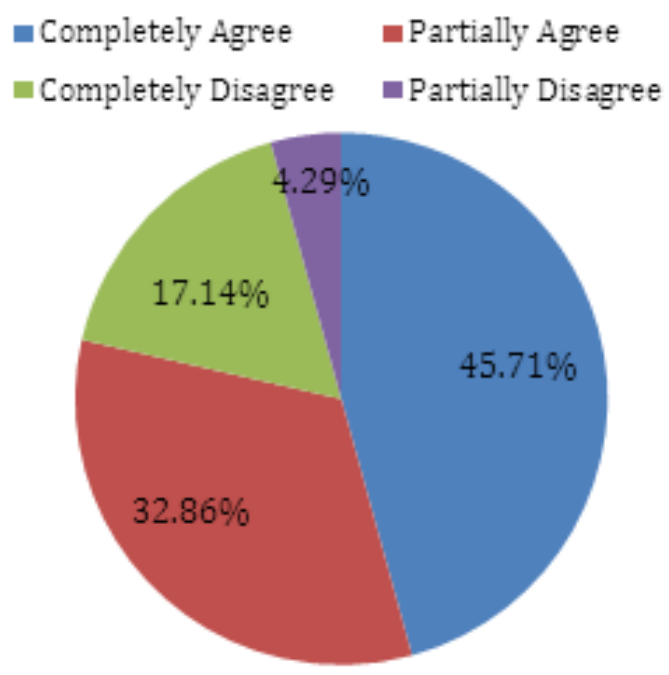

Men are by nature sexually polygamous/ tend to have more than one sexual partner

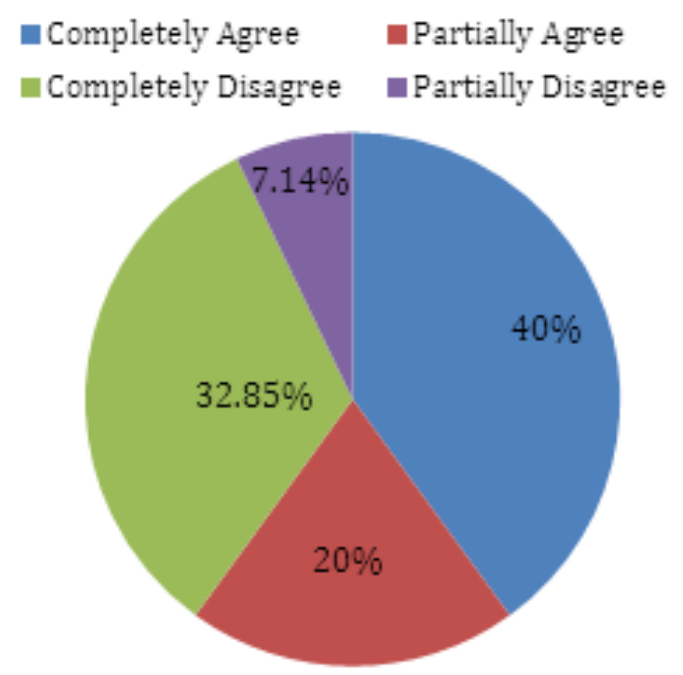

A boy/man can have affair with several girls simultaneously (as long as he can hide it from others) 


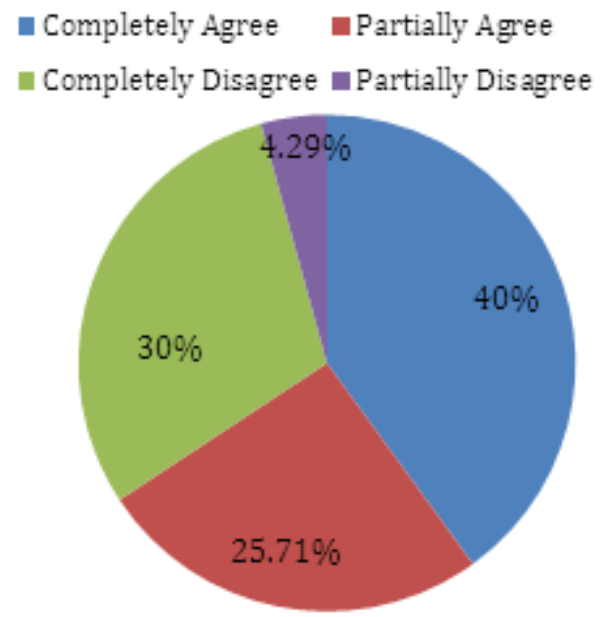

A man/boy can pay for sex or go to a sex worker to gain experience of making love

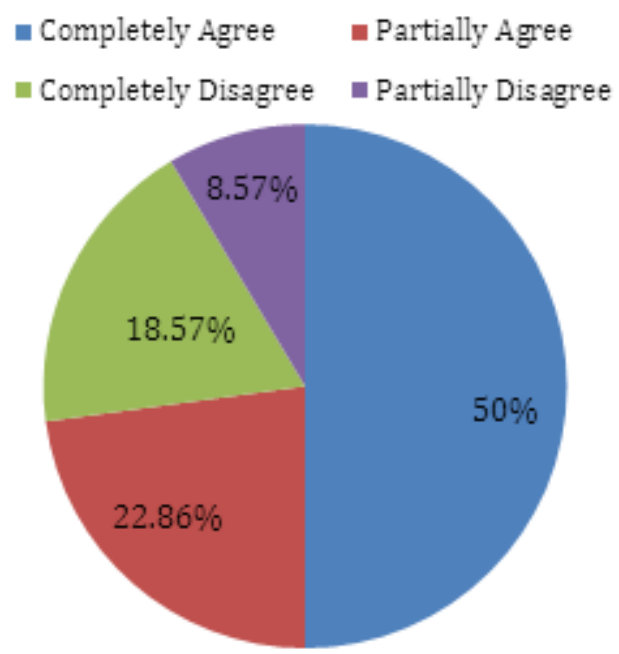

A girl/woman cannot pay for having sex with others
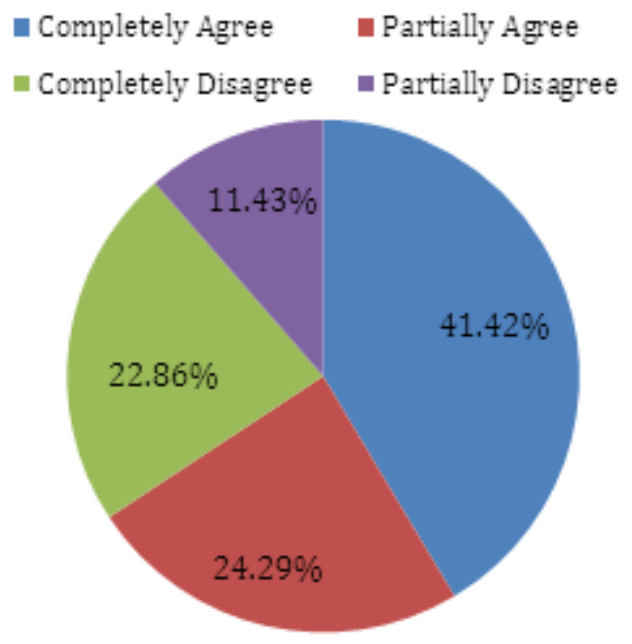

It is okay for a boy/man to have sexual relationship with girls before marriage

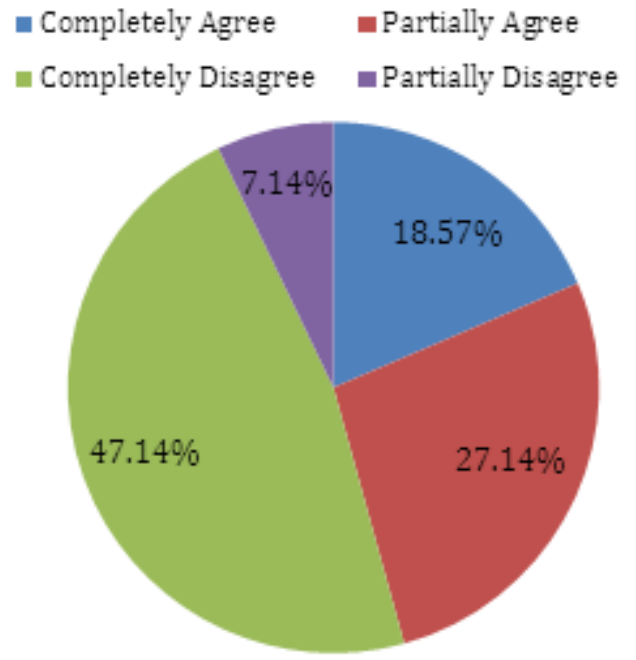

It is okay for $\mathrm{girl} /$ woman to have sexual relationship with boy/man before marriage

\subsection{Social Norms and Contradictory Masculine Identities}

Life history and other interviews with the professionals working in the field reconfirmed most of the findings of the survey, while also bringing forth new perspectives to understand the relationship between masculinities and violence against women. First and foremost, they revealed the fact that contemporary, especially urban, Nepali identities are contradictory rather than stable, and that the same person might show both gender violent and gender sensitive behavior at various moments of his life. Life history interviews of Bijaya Rayamajhi, an unemployed middle aged man living at Taudaha at the outskirts of the valley clearly showed such contradictory behavior concerning gender.

Bijaya Rayamajhi, 54 years of age, is of middle class Kshatriya caste and has been living at Taudaha for nearly twenty years.

He grew up in eastern hills of Nepal, in a family that was very patriarchal and where women did all household works. There was a great expectation on young men of the family to study hard, to develop a successful career, to make money and to make the family famous. There were no similar expectations on young women in the family. They were not even sent to schools because the elders felt that they will leave the family after marriage and go to a different "kul" or family with a different surname.

While he has worked as part time actor in Nepali films and $\mathrm{TV}$, Bijaya has remained mostly unemployed throughout his life. His wife Kumud teaches in a public school and is the main breadwinner of the family. They have two college going children who, according to Bijaya, are doing extremely well in the college

In his daily life Bijaya displays various forms of gender sensitive behavior. He engages in domestic duties like cooking, cleaning, and taking care of children. Also, he does not believe in beating the kids, thinks child marriage and 
dowry systems are wrong, and is okay with women taking initiative in matters concerning sex and romance. He is even fine with his daughter having pre-marital sex as long as she does it secretly and safely, despite that fact that it might bring disrepute to the family.

During the interview Bijaya said that his liberal attitudes are due to his education ( $\mathrm{He}$ did his bachelors from Darjeeling), his love of reading, and his subsequent migration to Kathmandu. He also admitted that he would have been a different man had he remained in the village with its patriarchal mind set.

As the interview progressed, however, it became obvious that despite his modern, urban liberalism, Bijaya holds a number of traditional stereotypes concerning the attributes of masculinities and femininities as can also be seen in the answers to the following questions:

\section{Q: Can men and women be equal? Are they equal?}

Bijaya: This is not possible, not according to the nature. Their bodies are different, and so are their abilities. Women have less physical ability then men. Even their mental abilities are less. Some people might say that Nepali women are below men socially or economically because of patriarchy. But take other nations: from sports to politics, music, and science you see mostly men in all domains. This is because nature has made men more powerful than women.

Q: How are men more powerful than woman in terms of mental abilities?

Bijaya: Their memory power is lesser than that of men. Also, women have less reasoning and logical power. Men lead not only in the material domains but even in the field of spiritualism: Kabir, Mahaveer, Buddha, Jesus ... they were all men. And those who preach in the religious Indian TV channels are mostly men. It is difficult for women to think deeply about any subject. Mozart, Beethoven, Leonardo da Vinci, Raphael, Socrates, Aristotle, Plato, they were all men. All this shows that nature has made women weaker than men Q: Are there some 'womanly' qualities that men do not have in equal degree and kind?

Bijaya: Yes! Nature has made women sahansheel (tolerant). They need to remain patient and bear the discomfitures of pregnancy for nine months. Even after giving birth they need to breastfeed the baby for months. This requires lots of patience. Even in the animal and birds you can see the same. Nature that made women sahansheel, less aggressive, less prone to anger, and with greater capacity to forgive in order to give continuity to existence

Q: Have you had quarrels with your wife over your twenty plus years of relationship? Have you come to blows ever?

A: Never. No blows even a single time. But we have had minor quarrels.

\section{Q: What type of quarrels? Who starts it usually?}

Bijaya: We don't quarrel these days because I have stopped drinking alcohol since last year, but we used to have quarrels before when I was still drinking every day. Later, when she came to know of my extra-marital affairs, then, too, she quarreled.

\section{Q: Did you have extra-marital affairs? How many?}

Bijay: Four so far! But I had only one extra-marital at one time. With the two of those women I had very short flings but with the next two I had longer relationships: three and half years with one, and four years with another. Among these last two one was from Jhapa, and another from Taudaha, the village where I live now.

Currently I am thinking of having another affair but I don't have money for it. If you have an affair you should take the women around. You should make them see places. We should not only think of how to get favors from women; we should also give something in return. I cannot give them money. So I try to take them to places they have not visited. Also, you need to feed them well during these trips. This is my dharma.

What is interesting is Bijaya's utter lack of sensitivity concerning his wife's feelings when he spoke of his extra-marital affairs. This was not surprising, however, when we consider that most people think men are naturally polygamous, as also revealed by the survey. Since most people still think that it is okay for married men to have affairs unlike married women, Bijaya did not feel anything amiss when he talked of his extra marital flings in the same breath while positioning himself as a liberal modern man with gender sensitive attitudes.

The researcher recently met Kumud, Bijaya's wife and the primary bread winner of the family. She was, unlike her husband, reticent about talking about her marital relations and even more hesitant about expressing her views concerning extra marital affairs. She opened up slightly, however, after a series of meetings at their home at Taudaha.

Q: Is it true that you are the main breadwinner of the family whereas your husband has remained mostly unemployed?

Kumud: This is true

Q: Who does the household chores, caring for children and other domestic duties?

Kumud: I do most of the cooking, but he helps in preparing food. He cuts up the vegetables and also does shopping in the afternoon when I am teaching at the school. There is a maid who comes help wash the clothes, though some of it I do myself. Both of us used to take turns to help the children in their homework when they were kids, but now that they have grown up we don't need to do that

Q: Did you have to face any social problem due to the fact that it is you, instead of your husband who earns the money for the family.

Kumud: I personally don't have any problems with it. I am educated up to bachelors level and like to read books He also likes to read. This has broadened our thoughts. But some of my friends, including my women fellow teachers at the 
school pass sarcastic remarks sometimes, suggesting that it is better to be the mistress of a real marda than be a wife of a namarda. They also say that a man who cannot make money for the family is not a real man. Some of his male friends have told him the same, and on one occasion he lost his cool and fought with that man.

\section{Q: Have he ever shown aggression towards you?}

Kumud: Only once or twice when he was drunk, at a time when we were having personal problems. At other times sometimes we fight, but only verbally. I think that is natural for most couples.

Q: Did he use physical violence towards you at those times?

Kumud: Yes he slapped me once, and at another time, pulled my hair so hard that I felt the pain for the entire day. Men are aggressive; nothing can be done about it. It is their nature, but he is not as aggressive as some of the other men in the locality. Our neighbor's husband beats her at least once a week.

Q: What was the immediate cause that led him to display physical violence towards you?

Kumud: It was after I came to know of his latest extramarital affair. I am not the kind of woman who cribs about such things. There are many things I have overlooked, thinking it in the nature of men to be promiscuous. Men are like that. But there should be limitation of everything, and people should know their limits. Also, he was squandering money over those silly women. So I told him that I can't take it anymore. I am after all working so hard to keep the ends going. He just reads newspapers and relaxes, and despite the fact that some of my friends think he is a namara, I have remained loyal to him so far. It was then he lost his temper and slapped me.

These two interviews showed some obvious contradictions. Bijaya had claimed that he does the bulk of household chores whereas Kumud said that they do it together. Also, he had told the researchers that he has never assaulted her physically; a fact that was contradicted by his wife. Both of them were more liberal concerning gender roles compared to their less educated neighbors. At the same time, Kumud, just like her husband, had internalized the same old stereotype concerning masculinities: that men are born aggressive and polygamous; a fact that is also attested by the results of the questionnaire survey. In addition, it was instructive to note the two moments when Bijaya lost his temper and used physical violence: first towards his male friend, and second towards his own wife. In both cases, the subject that he is not a true man (real marda) because he does not earn, had come up. It is possible that he used physical aggression to deal with the sense of psychological lack generated by the suggestion that he is not a real man.

\subsection{Law and Custom: In between Spaces}

The interviews of Chandra Nagarkoti and Bhesh Raj
Nepal, the first charged of rape and the second of attempted rape, also showed that many men think and behave within an in-between space shaped by both law and custom. While such men have some knowledge of ethical or state laws concerning certain activities that are understood as violent, they might continue to engage in those activities due to received ideologies that men are naturally aggressive and polygamous.

Chandra is 25 year of age and used to work in a dance restaurant as a waiter/ barman and part time dancer before he was charged of raping a waitress from the same restaurant. Since Chandra was born in a very poor family (his father was a wage laborer) he was forced to give up his studies after grade three and began earning money for the family. He then left his village and started living in a rented room to work in various restaurants and bars of Kathmandu He also met and married a Tamang woman living in the same building in which Chandra had one room apartment. She later migrated to Kuwait for work a year ago against his wish and they are not in touch following her departure. Following this, Chandra has been taking care of their now nine-year daughter by himself, cooks meals for her, washes her clothes and takes her to school, thus displaying perfect gender sensitive behavior.

Chandra Nagarkoti was handcuffed when the researcher met him at the police station. The charge of rape that was leveled at him pointed at gender violence of worst sorts. At the same time, the interview revealed a hardworking man who was extremely caring when it came to his daughter

Q: Tell me about this girl, the one whom you are accused of raping. How did you meet her? How was she like?

Chandra: She had just joined the dance restaurant at Durbarmarg where I was working. She was from outside the Valley and did not know much about the city. Two days before the incident she sent me sms asking if I had taken my lunch. I thought she was interested in me. That day the minibus (organized by the restaurant owner) did not come and she called me asking how she should go to the restaurant. I suggested that we could go together if she comes to my room. She came around $5 \mathrm{pm}$ and we began talking.

I lost control after a while, and tried to touch her. (You should realize that I have been living without my wife for more than a year and half after she migrated to Kuwait). She kept saying no in the beginning but then got excited and did not protest and so we had sex with mutual consent. After the act she behaved normally and we took public transport together to reach the restaurant. I sat in the hall she disappeared behind.

\section{Q: What happened after that?}

Chandra: After some time they called me to the kitchen where she was sitting with other girls from the restaurant, weeping and accusing me of raping her. I said what we did was with mutual consent, but no one believed me. Soon, police came and took me to Durbar Marg police station. There they beat me up and made me naked to check if there 
were some signs of fighting in my body. They brought me to Hanuman Dhoka prison after that. I have been here for the last twenty-two days.

How could I have raped her? If I had really tried to rape she could have shouted which she never did. I think one man cannot rape a woman. You need at least three or four men to rape a girl. One has to grab her hands, another must put his palm on her mouth to stop her from screaming. And there must be wounds or signs of violence on the body. But none of this was true in this case.

Q: Was she scared of you? Is it possible that she didn't cry out because she was scared?

(Long Pause. No answer)

Q: Is a woman's no always a no? How is one to find out?

Chandra: If the girl likes you she might say yes immediately when you propose. Some of them say no at the beginning, but then agree if you keep on exciting her by playing with her body. Some of them might even take 2, 3 months to agree and want to fall in love before having sex.

Q: Who is a real marda? And what about namarda?

Chandra: I don't know much about this really. In my view a man is real man who works for the family, who does good things and does not go against the law. I was a marda till last month. Yes I was poor, but I was taking care of my daughter. Now look at this (points to the handcuffs). Now probably I have become a namarda as I am outside the law. ${ }^{2}$

Interview with Chandra revealed that he thinks it okay to touch the body of a woman even if she keeps on saying no. His argument was that if the girl gets excited later and agrees for sex, the man should not be held accountable for his initial transgression. While Chandra agreed with the survey question that it is an act of violence to have sex with a women against her wishes, he was simultaneously directed by the customary perception that man should make the first move in matters related to sex and romance, and that it was okay for a man to be aggressive in these matters despite refusals by a woman. This because if a man does not act aggressive in such matters he might be considered, not only by others but also by the woman involved in the matter, as a a namarda,

It was difficult to find Ramyata, the woman allegedly raped by Chandra Nagarkoti. Inquiries at the dance restaurant where she was working prior to the act of sexual violence were unfruitful with some of her fellow workers saying that she had gone back to the village, whereas others saying that she had migrated to Qatar. After two weeks of frantic search, following the help from a male waiter working in the same restaurant, the researcher found her working part time in a dohori restaurant in Thamel, the tourist hub of Kathmandu. She was still working as a waitress but, after receiving support from Raksha Nepal, an

2 The word marda signifies "real man" in Nepali just as namarda means someone who is less than a man, or a man who is lacking masculine characteristics.
NGO that helps poor women and children suffering from sexual violence, was training to be cook. She also had plans to migrate to either middle-east or Malaysia following the completion of her training. At the first meeting she refused to talk of the incident but agreed to share some of her experience after being assured of anonymous representation during the second meeting.

Q: According to Chandra, you had sent him a sms the day this incident happened, and also that you had arrived at his apartment willingly. Is that true?

Ramyata: That is true. I had just arrived at the city from the village and I didn't know anyone. He seemed like a good person. I needed some support at that time, a friend.

\section{Q: Were you attracted towards him?}

Ramyata: I just thought he was a good person. And since we were working in the same restaurant, I thought I could trust him. If things would have continued normally, it is possible that we would have gotten closer. But he just took advantage of me that day. No, I don't think I was attracted towards him.

Q: Weren't there other people around in the nearby rooms? Why didn't you shout, asking for help?

Ramyata: I was just too scared. Such thing had never happened to me before. I was not sure whether to shout or cry. When such things happen in our village it is a big matter. The reputation of the woman is ruined forever. I thought the same thing might happen in the city. And at that moment I thought of my father. He was against me migrating to the city for work. He wanted me to marry a village guy, much older in age and a drunkard. It was to avoid that marriage that I came to the city. I thought what would my father say if he knew that a city man had taken advantage of me? Also, I didn't know any city people. I didn't know how they react in such situations or how I was expected to react or behave.

Q: In the police records Chandra has stated that you were behaving normally and smiling when, after the incident, you both went together to the dance restaurant, and that you reported him only after reaching there. Is this true?

Ramyata: I was not smiling. I was just too nervous and too scared to say anything. After we reached the restaurant I met didis (older sisters) working in the same restaurant. I think they saw I was nervous and realized something was not right. When they asked me I could simply not control myself and began to cry. After they continued to insist, I told them what had happened earlier.

This interview merely confirmed the "masculine blindness" that had surfaced during Chandra's interview. Chandra felt that she had shown romantic interest by sending him sms and then coming to his room by her own free decision. He also felt that, as a man, it was up to him to initiate sexual contact. He also said that she was only making a show of resistance, and that she wanted to have sex as well, as also that she would have shouted if she did not want it 
What he failed to realize that she was looking for a friend in an alien city, instead of a sexual partner. In addition, as his silence showed when confronted by the same question, he remained blind to the possibility that she did not shout during sexual misconduct for help because she was scared and was concerned about ruining her prestige. This only shows the persistence of traditional stereotypes concerning both masculinities and femininities in Nepali society: a man one is expected to be aggressive in matters related to sexuality, and that a woman's purity is lost when men take advantage of her body in illegitimate manner. This is one of the reasons why only few women victims report rape cases at police stations, whereas male perpetrators of sexual violence remain unpunished as also discussed in the section below.

\subsection{Social Structure and Limitations of Law}

Contradictory attitude towards masculinity was also shown by Bheshraj Nepal, a 43 year old lower middle class man charged of attempting to rape a lati (a woman who stutters, or cannot speak properly) whom the researcher met at New Baneshwor police custody. Bheshraj claims to have lost his nerve at the last moment when feelings of guilt overcame him (he did not actually rape her) as he thought of his wife who was returning to Nepal in a couple weeks from Dubai after working there for a few years. The officer in charge had shown Bheshraj's file to the researcher before the latter interviewed Bheshraj. In that file was Bheshraj's self admission that he had attempted the rape.

Q: How were you charged for attempted rape? What exactly happened?

Bhesh Raj: I am surprised about the charge. I used to eat food in a restaurant at the ground floor of a house. Later I began living in the same house after gharpeti baini (landowner's sister) said that she would give me a room for just 2500 per month. There was also a cabin near the restaurant and, as dashain festival approached, people began playing cards in the cabin. I used to watch them play. She (lati) used to watch us. She was supposed to be a distant relative of the landowner bahini. She also used to serve us food in the restaurant. She could not speak properly.

Q: But what led to the rape charges? What actually happened that day?

Bhesh Raj: I had spent the entire day playing cards. In the evening I went up to my room. It was kind of hot. I took off my shirt and then later pants after wrapping a towel around my waist. It seems that she was in my room (he was vague about whether she was already in the room when he reached there or came afterwards) to pick up cups from the restaurant. Since she cannot speak properly and does not understand well I asked her in English. "Why?" Then I asked her to go, again in English. At that time I saw a man in white clothes from the windows. He began to shout. Soon a lot of people began shouting in loud voices, and came up to accost me. But I have not done anything. I told them to check her body and find for themselves if I had raped her. One gets poisoned only if one drinks poison. Poison that one has not taken cannot affect him.

Q: According to the police officer in charge at New Baneshwor Police station you are charged for attempted rape. He also said that your initial statement was that you wanted to have sex with her, but later felt guilty when you thought of your wife and family and changed your mind. Is this true?

Bhesh Raj (Taken aback): Oh ... is that what it says in my statement? Sometimes it is natural to feel emotional like that, especially when one's wife is away. But I was telling her to go in English. I have not even touched her. I just heard people shouting through the window. It is possible that I made some mistake too. You imagine yourself. They can test her body.

\section{Q: Do your wife or children know about this?}

Bhesh Raj: No they don't know anything. I don't want them to know. My wife is coming from Dubai. I want to get out of the prison before she does. Please trust me. If you spread my story via newspapers or other means it wont be nice of you.

\section{Q: Were you drinking alcohol that day?}

Bhesh Raj: Yes right from the morning.

Q: What is the ethnicity of the women you are accused of trying to rape?

Bhesh Raj: The landowning bahini is a khadka. The lati I think must be either a Gurung or a Magar.

As the researcher came out of the police station he was met by two people, one man another women, who had come to try to convince the police officer to free Bhesh Raj. Further inquiries revealed that they were trying to strike a compromise, probably by giving money to the victim. Later, the researcher came to know that Bhesh Raj was set free after the victim withdrew her charges. This points to the socio-economic advantage that the perpetrator of violence enjoyed in relation to his victim: he belonged to lower middle class whereas she was from a working class background; he had received education up to SLC level while she was illiterate; he could utter English words while she could only stutter, and he was an upper caste bahun whereas she belonged to the minority caste. Such mismatch in power relations cannot be ignored when we study gender-based violence. While not all men in greater positions of power commit violence against those who have less power, there is always a possibility that power may be misused. And as the case shows, there is a greater chance of the perpetrator escaping punishment if he is more powerful --economically, socially or culturally--than the victim. This observation is also supported by the research findings that more people from lower income and educational background suffer sexual violence when compared to those who are from higher income and educational brackets.

Such a mismatch in power relations may lead some people 
to believe that they can get away with minor sexual infringements. In the opinion of Bhesh Raj, for example, rape was a major crime whereas attempted rape was not; it was a crime that could be forgiven if attempted by a man living without his wife upon a stuttering, uneducated woman. In other words, like Chandra Nagarkoti discussed earlier, Bhesh Raj's action, too, happened in an in-between space suspended between law and custom. While he knew that rape was an act of violence that was legally punishable, he still attempted it because he thought this much was permissible according to custom as well as social structures supporting that custom. The subsequent events leading to the withdrawal of the case merely proved him right.

\subsection{Law, Social Norms and Discrimination}

Interviews of lawyers like Meera Dhungana and Shashi Adhikari who have fought important legal battles concerning women's rights, showed that it is difficult for women, especially those who have been victims of violence, to obtain justice because of various factors: discriminatory laws, slowness of legal process, persistence of patriarchal social norms and predominance of men in law implementing institutions. Meera Dhungana, for example, said that despite some positive changes recent years, men and women are still not equal in the eyes of Nepali law.

Q: You are working in the legal field for a long time. Some positive laws have come into being in the last few years concerning the rights of women. And yet, many women are still finding it hard to get easy and equal access to law. What is the reason behind this?

Meera Dhungana: This is because there is still discrimination in the legal system ... and women continue to be discriminated in terms of property rights. It is true that the current law assures birthright to women concerning property rights, but they can enjoy that right only if they get property via anshabanda or legal division of parental property before they get married. In other words, if a woman already has her share of parental property before she gets married, she does not have to return it after marriage. But if she does not have property at the time of marriage, she cannot even claim for it later. Sons don't have to face similar discrimination.

\section{Q: Can this lead to violence? How?}

Meera Dhungana: Because of the legal and social systems according to which women have to go to their husband's house after marriage, they become dependent upon their husbands. She can gain independence only if she can enjoy continuous property rights. Sons can exercise their property rights continuously from the time of birth to death. But the daughter has to begin all over again when she marries and goes to the boy's house. Her property right stops in relation to her parental home and begins again in relation to her husband's home. There is no continuity of property rights as far as women are concerned. Even the interim constitution of 2063 has not been able to establish equality in this matter.
Any right should be continuous. When the right is broken somewhere this can lead to discrimination and that discrimination leads to violence.

Both Dhungana and Adhikari stressed, however, that law was only part of the problem, and the main obstacle to gender justice were the patriarchal social norms that pervaded the mindset of the people who were in law implementing agencies.

Q: Will women have equal access to justice if all laws are made totally non-discriminatory?

Meera Dhungana: It will be difficult even then because of the power of patriarchal norms and the thought process of men who occupy high positions in the institutions supposed to distribute justice. But if we have non-discriminatory laws that will create a ground from which one can protest, fight, or spread awareness.

Sashi Adhikari: It is difficult for women to get an equal access to law under present circumstances. It does not matter whether men belong to the implementing agencies, political parties or civil society - most of them have negative attitudes. Even if there is a severe case of violence against women, their first response is to tell the women to forgive their partners and reconcile. Some positive rules have come. Eleventh amendment in the law was one such positive step as it established equal property rights for men and women. But similar change has not transpired in the attitude of people. Mindsets of many men who are in the corridors of power and in implementing agencies remain the same.

Other interviews conducted during the research also showed showed how mass media affects the contemporary associations between masculinity and aggressivity with Dewan Rai and Netra Acharya (the two journalists who were also involved in Occupy Baluatar movement fighting for gender justice in Nepal) saying that influence of Hollywood and Bollywood films reinforce the traditional ideology that a man should be macho, as also the idea that there is a natural connection between masculinity and aggression.

Q: What are the social perceptions concerning marda and namarda, And your own views regarding this?

Dewan Rai: When I was growing up Rambo films came up. Those films promoted the idea that real marda is a person who has muscular body. Hindi films also promote the idea that a real man must be strong and muscular. In Bollywood films there are repeated references to the question as to who is real marda and who namarda. Such films reinforce the idea that real man is violent, aggressive and muscular. Personally I don't believe in all this. I had a different definition of masculinity even when I was growing up. I always thought traditional definitions concerning marda and namarda were fallacious. I always thought muscles do not always make a man. Knowledge is more important.

Interviews also showed that traditional social norms concerning men and women pervade most social fields, including legal and media sectors. Sashi Adhikari, for example, admitted the fact that "many lawyers -both men 
and women--suffer from gender blindness" and suggested "that there should be a compulsory course on gender in Nepal judicial academy." Dewan Rai, a senior journalist working for The Kathmandu Post similarly admitted that there is massive gender insensitivity in the field of media.

Q: There is a perception that there is a lot of gender insensitivity among those who are in media. Is this true? If yes why? Journalists know a lot about gender equality and so on, don't they?

Dewan Rai: Most of the people in media are not well educated. There are no minimum educational standards for joining media. And most of them don't have multicultural awareness. They don't have any knowledge of sociology and don't understand know human selves are socially constructed. In recent times some educated people have entered the field. But the journalists of the older generation keep on passing their "wisdom" onto them. Journalists hardly raise issues concerning women's empowerment. Few days ago, list of First past the post (FPTP) candidates for upcoming constituent assembly elections was made public. The interim constitution ensures 33 percent representation of women in all social bodies. Despite this there are only 10 percent women in the FPTP list. But media is not raising any voice against this. The field of media is populated by men.... and editors and reporters are remaining silent.

\subsection{Social Norms, Law and Social Structure: Public and Private Domains}

Dewan Rai's comments stressed not only the issue of social norms, but also pointed to the bare fact that most public institutions and professions are largely populated by men, especially so in the leadership positions. What adds to the problem is that not only are men in "leadership positions" in the social institutions but also within the family unit, with women doing most of the household chores and men performing breadwinning roles. Women are thus doubly disadvantaged, both within the private space of the family and the public space of wage labor. Such disadvantage experienced by women in their daily lives has deep implications for matters related to gender justice as was also suggested by Meera Dhungana in relation to the issue of marital rape.

Q: What do you think about the law concerning marital rape?

Meera Dhungana: There is a law about it, but it is hardly exercised. This is because even if a woman decides to file a case against marital rape, she still has to go back and live with the same husband, in his house, while the case in going on. Following this, he might scold or beat her further for filing the case against him. She also has to take care of the kids as men often don't share child-rearing duties. For this reason she is totally dependent upon her husband. How can the marital rape law be exercised under such circumstances?

$\mathrm{Q}$ : What is the punishment for marital rape?
Meera Dhungana: The husband who perpetrates marital rape can only be imprisoned for three to six months (as opposed to general rape cases when the victimizer can be imprisoned up to fifteen years). One might ask why such mismatch in law? The answer is that those who make law are men. Violence often happens within the house. A woman might think that the space of the home is where she is secure. But what is she to do when it is within home that she experiences violence?

Q: Are institutions such as police force and legal courts gender friendly for women?

Meera Dhungana: No. For the simple reason that there are so few women in those institutions. When Babu Ram Bhattarai was prime minister a law was passed saying 1000 new women would be given entry into the police force. That never happened. Law also says that there should be 33 percent women in all governmental bodies. But in the FPTP list for the 2013 CA elections there are just ten percent of women, that is just one percent more than what it was in 2008 CA elections.

Dhungana also argued that after the re-establishment of house of representatives in 2063 a number of clauses were passed: 33 percent women representation in every state organ; citizenship under mothers name; end of all violence against women; and equal rights in relation to parental property. All this was passed with the agreement of all political parties. But after the andolan was over and things settled down it was back to old ways. It shows that all that was mere posturing, they wanted to show how liberal and modern they were.

Interviews with lawyers such as Meera Dhungana and Sashi Adhika further revealed the problems women have to face as they seek justice after being victims of violence. When they approach police, for instance, the often have to deal with male members of the police force telling them to resolve their differences with their husbands. Sashi Adhikari pointed to the fact that in earlier days, women used to compromise and suffer silently as there were no laws to protect them. Now they know that there are laws, but when they try to gain access to those laws it does not bring any change in their situation. And in some cases, they might have to suffer even more after they return to their husband's houses following consultations at the police station. The husbands might take advantage of such situation and threaten or beat them for reporting them to the police. Adhikari argued further that this can lead to frustration and total breakdown.

All this shows that the problem of law implementation is directly related to the problem of social structure, including its various public (police stations and courts for instance) and private (family) institutions, in which men are enjoy greater position of power compared to women. Further interactions with Sashi Adhikari and Dewan Rai clearly pointed at such nexus of social structure and law.

Q: How strong is the presence of women in the law implementing agencies? 
Sashi Adhikari: In the law implementing agencies men outnumber women by a whopping margin. Women find it difficult to share their problems with men. The women's cell in Kalimati Police station is functioning well. But even there, the immediate superiors of women police personnel are invariably men with the same old patriarchal mindset.

Dewan Rai similarly pointed to the mismatch between male and female representations in the public institutions and suggested that violence against women can only be reduced if we have proportional representation of women in social bodies, especially in the law implementing agencies like police, courts and local bodies.

Q: What steps should be taken to reduce violence against women?

Dewan Rai: There is no magic bullet. The main thing is to change people's perceptions. And women's presence should be increased in all fields. Recently, local autonomous governance law was changed. As per the new law 40 percent of women's participation in local bodies is guaranteed. If this law is applied strictly, 100, 000 women will enter state mechanism. At this point we need numbers rather than merely stressing quality. When people see large number of women in non-traditional fields social perceptions regarding them will change as well. You don't see women in village level meetings even to this day. And if a woman drives a car or a big size motorcycle in the city people are still surprised. This shows that general perceptions regarding women remain unchanged. Such perceptions will change as more women enter state and non-state mechanism in high numbers.

\section{Conclusion: Patriarchy and Violence against Women}

Both the survey and life history interviews revealed that socio-cultural and legal institutions are not only shaped by the circulation of patriarchal social norms concerning masculinities and femininities - that men are naturally aggressive, polygamous, rational and with greater bread winning abilities than women-but also by the sheer overwhelming presence of men in the social institutions, including parliaments, courts and police stations. In this regard social norms and social structure mutually support each other. During the survey many respondents said that leadership quality and political affiliation are two of the major characteristics of men. This is a matter relating to social norms, but such deeply internalized norm is also supported by the visible presence of more men in leadership positions - whether in the private domain of the family or the public domain of the nation, including professional fields ranging from politics to law and media. This was precisely the point made by Bijaya Rayamajhi, one of the respondents whose life history showed how even so called liberal men can continue to hold onto traditional social norms. This is why it is difficult to change social norms or belief system when the underlying structure remains the same. Under such circumstances perpetrators of violence often escape punishment as was also shown by the life history interview of Bhesh Raj Nepal as discussed earlier.

At the same time, a mere change in the structure will not be sufficient. This is because women or TG subjects who might gain entrance into the legal and political systems, due to the changing, more liberal laws, might have internalized the same patriarchal social norms that turn them into victims. As the survey also showed, many women and TG subjects believe that men are naturally aggressive, polygamous and have bread-winning abilities. If women or TG subjects with such gender biased social norms enter socio-political structures they will not be able to contribute much to change the system. Instead, we might see the cases of women repressing other women, or transgender subjects repressing others from the LGBTI community.

Finally, the making and practice of law cannot be considered free from the pressures of both social norms and social structure. Since legal spaces are shaped by both patriarchal social norms concerning how a man or woman should behave, as well as by the visible presence of men outnumbering women, this can affect both the making of law as well as its everyday practice. This in turn can encourage perpetrators of violence to act in an in-between space, one that is suspended between law and custom, as can be seen in the cases of both Chandra Nagarkoti and Bhej Raj.

One sees more men in social structure, that social structure reinforces social norms just as norms support the structure, and a combination of structure and norms shapes the making and practice of law. For this reason, any attempt to create a gender just society needs to tackle these three aspects of patriarchy simultaneously. These three aspects function as three heads of the mythological hydra, cutting one head would make any difference because, as long as the other two heads remain, the severed head regrows again. Only way to kill such a hydra is to deal with all three heads, or these three aspects of patriarchy, simultaneously.

\section{REFERENCES}

[1] S. Benjamin. Challenging Masculinity: Disability and Achievement in testing times, Gender and Education, Vol. 13, No. 2, 39-55, 2001.

[2] A. Broom. Prostrate Cancer and Masculinity in Australian society: A case for stolen Identity?, International Journal of Men's Health, Vol 3, No 2, 73-91, 2004.

[3] J. Butler. Bodies that Matter: On the Discursive Limits of "sex," New York, Routledge, 1993.

[4] R. Connel. Masculinities, Sydney, polity press, 1995.

[5] D. J Khati. "Masculinity among Dalit men and boys in Dolkha district of Nepal" SANAM, 2011.

[6] M. S Kimmel. The Gendered Society, Third edition, Oxford: Oxford UP, 2008. 
[7] M. Maycock, Matt. Masculinity, Modernity and Bonded Labour: Continuity and Change amongst the Kamaiya of Kailali District, far - west Nepal, Ph.d Thesis, University of East Anglia, 2012.

[8] P, Onta. Creating a Brave Nepali Nation in British India: The Rhetoric of $J$ ati Improvement, Rediscovery of Bhanubhakta and the Writing of $B$ i $r$ History," Studies in Nepali History and Society, Vol. 1, No 1, 37-76, 1996.

[9] J. R. Sharma. Men's participation in the Maoist Insurgency in Nepal. Online available from http://www.devstud.org.uk/aqa dmin/media/uploads/4ab7808bbef9b_6-sharma-dsa09.pdf.

[10] S Uprety. Masculinity and Mimicry: Ranas and Gurkhas, Kathmandu, Baha Occasional Papers 5, 2011.

i The paper is based on an earlier research done under the aegis of UNDP and MenEngage (Nepal) and was conducted from September to December 2013. 